\title{
Rypestek etter forløsning
}

Dette er en merkelig tekst. Hva er det forfatteren vil fortelle oss? Hvorfor forteller han denne historien nå - 30 år etter at den fant sted? Og hvorfor kaller han den drøm og virkelighet når den handler om noe så håndfast og lite drømmeaktig som et rypebein i endetarmen? Spørsmålene trenger seg på, men har ingen klare svar. Men folk lønnet sine hjelpere bra før i tiden rypestek er det vel få legevaktleger som blir tilbudt for tiden. God jakt - og pass på de små beina! (Tidsskr Nor Lægeforen 1926; 46: 516.)

\section{Drøm og virkelighet}

\author{
Av C. Wingard, Dale asyl.
}

En dag (det er nu henved 30 aar siden) kom der til mig en mand, som fortalte at «konen igaar nat hadde drømt, at hun fik saa overhændig ondt i endetarmen». Da hun vaaknet, var imidlertid smerten der fremdeles, og siste nat hadde hun ikke faat sove for smerter i ovennævnte organ. Jeg kjendte godt konen bygdens jordmor og et sundt og friskt menneske i 60 aars alderen. Forsynt med nogen utensilier, hvoriblandt en smal korntang, fulgte jeg med manden til hans hjem, hvor jeg fandt konen tilsengs; naar hun sat oppe eller gik, var smerterne værre, forklarte hun. Ved eksploration støtte fingeren paa et tyndt, litt eftergivelig corpus alienum, som sat paa tvers i tarmen straks ovenfor sfinkter. Med den omtalte korntang lykkedes det at fatte nævnte corpus, som efter ekstraktion viste sig at være det gaffelformede kraveben av en rype. Nu husket pat. at hun kort tid i forveien efter en vel tilendebragt barselforretning var blitt traktert med rypestek, hvorved hun som var gammel og tandløs vistnok var kommet i skade for at sluke benet, sulten som hun ogsaa var. Hun var saa uvant med at være syk, sa hun, at hun rent var kommet ut av sig gode skind, men nu hadde hun atter faat sit gode humør igjen og takket mig hjertelig for den «vellykkede forløsning» som hun sa. Efter hvad jeg senere hørte, kom der ingen komplikationer, og hun befandt sig fuldstændig vel. 